\title{
The Effect of Grazing on the Production of Grasslands in Hilly Areas
}

\author{
Zorica VOȘGAN $^{1 *}$, Roxana VIDICAN ${ }^{2}$, Lucia MIHALESCU ${ }^{1}$, Oana MARE ROŞCA ${ }^{1}$, Monica MARIAN ${ }^{1}$, \\ Beatrice SZILAGYI ${ }^{2}$
}

${ }^{1}$ Department of Biology, Technical University of Cluj-Napoca, North University Center of Baia Mare, no.76, Victoriei Street, Baia Mare, Romania;

${ }^{2}$ University of Agricultural Sciences and Veterinary Medicine, Cluj-Napoca

* corresponding author: zori_v13@yahoo.com

Bulletin USAMV series Agriculture 71(2)/2014

Print ISSN 1843-5246; Electronic ISSN 1843-5386

DOI 10.15835/buasvmcn-agr: 10544

\begin{abstract}
The fodder production and the exploitation of pastures by grazing is an important activity in the livestock economy of the hilly regions of the Maramures County. Thus, the surfaces of the areas of the Surdesti village are alternatively used both by grazing and mowing, depending on the feed requirements. The production monitoring, following this mixed use by mowing and grazing is performed in order to observe the efficiency of this type of grazing. In the hilly areas near the settlements, grasslands are grazed during spring and autumn, as during summertime when the transhumance of livestock towards the mountain areas takes place the pastures are mowed for obtaining the feeding hay required in the winter. The global production is $13.10(\mathrm{t} / \mathrm{ha})$ on the surveyed pasture, resulting the coefficient of utilization of grass $\mathrm{K}=87.6 \%$. The pastoral mean value of the meadow is 1.9 , and it is sustaining a load of 0.81 to $1.00 \mathrm{LU} / \mathrm{ha}$, equivalent to 5.7 to $7.1 \mathrm{sheep} / \mathrm{ha}$. The analyzed lawn is of medium category which requires proper maintenance to increase its economic value. Thus, lack of basic maintenance works will lead to long-term unfavourable effects of the sheep and goat farms. Sustainable use of grasslands will be possible by practicing an organized grazing.
\end{abstract}

Keywords: grazing, meadow production, pastoral value

\section{INTRODUCTION}

The lately occurred economic and social changes affected the potential of Romania's pastoral heritage. Thus it is necessary to develop scientific research in the field in order to improve the agronomic function and harmonize the relationship of meadows - animal-human.

The irrational exploitation of grasslands leads to serious damages or even result in removal from the circuit of some inseminated areas of grassland. This occurs due to the abandonment or improper recovery mode by under-grazing or over-grazing. The effects of these actions are found today in low productivity grasslands. The dramatic changes towards intensification and abandonment that occuring in the grassland and agro-silvo-pastoral systems of many less-favoured area in the world (Caballero, 2007) can result in a general decline of grassland plant diversity and productivity (Bagella et al., 2013).

In the hilly regions of the Maramures County there are permanent pastures, consisting of plant species mainly belonging to two large families: Poaceae and Fabaceae. In most grassland ecosystems that are exploited by grazing, modifications in terms of floristic composition appear, their areas being invaded by plant species that deplete their economic value both quantitatively and qualitatively.

When the grassland is rich in diverse species of flora, animals tend to choose plants which meet best their nutritional requirements and when diversity is smaller, animals start to graze less selective (Metera et al., 2010). Generally, sheep and goats need more energy and they are likely selecting parts of plants (flowers, pods, buds) with 
higher nutritional value (Rook et al., 2004). Thus, it must be paid attention to the grazing mode, because this could lead to a decrease in the pasture productivity and a reduction of the pastoral value.

The maintenance of the balance of grasslands grassy carpetis an art that the pastures householder must thoroughly appropriate, starting with the knowledge of plants, the nutrient and moisture requirements thereof, the appropriate methods for use by grazing or mowing and other measures (Marușca et al., 2012).

\section{MATERIALS AND METHODS}

The research was conducted in a hilly area in the eastern part of the county of Maramures, on the communal pasture of Surdesti village. Here, the main livelihood of the inhabitants is pomiculture, livestock growing (especially sheep and goats), agritourism.

The land near the locality, about 70 ha, is primarily exploited as pasture for hay and grazing land and to a lesser extent as plowing land. The lawn is a type of mixed use, being alternatively used for grazing and mowing, depending of the needs of household fodder.

Sheep and goats grazing on the analyzed pasture takes place in spring and autumn, and during summer, when the animals are in the mountain area (pastures of the Gutai Mountains) the lawn is mowed giving necessary feeding hay for winter.

The pasture production was determined by the repeated mowing method, which involves determining the yield of green mass per area unit, after mowing and weighing of grass from the sample plots before each production cycle (Rotar et al., 2009). This method involves the following steps:

- Determining the number and area of the sample plots;

- Determining the total or overall pasture production $(\mathrm{Pg})$

- Determining uneatable remains or refusals (R)

- Determining the actual or eatable production of the pasture $(\mathrm{Pc})$

- Determining the grass using rate on the pasture $(\mathrm{K} \%)$.

The next step is the application of some formulas of determining the pastoral value as well as the grazing capacity, which indicates the number of animals that can be fed on the surface of 1 ha pasture, throughout the growing season.

\section{RESULTS AND DISCUSSION}

The ways of using a pasture as well as the environmental conditions influence the natural pastures of hills and mountains. The system of alternating use of pastures by grazing (during spring and fall) and mowing (summer) is the way of using pastures in the village Surdesti. The only way to improve the pasture production is carried out by traditional, inexpensive methods („târlitul”).

In terms of floristic composition, on the analyzed hilly pasture in Maramures County, the species of Festuca rubra is dominant, mostly contributing to the formation of production. Among Gramineae with forage value the following are found Antoxatum odoratum, Agrostis capillaris, Briza media, Cynosurus cristatus, Poa pratensis, and among fabacee Trifolium repens, Trifolium pratense, Lotus corniculatus have higher frequency. Species with lower coverage degree from other botanic families having some forage value are met Achillea millefolium, Alchemila vulgaris, Taraxacum officinale, Plantago lanceolata. Plants without forage value, low forage value or even harmful weeds as the species of Nardus stricta are met. In areas heavily fattened by sheep grazing, azotophile weeds have been installed Urtica dioica, Rumex sp.

According to Maruşca et al. (2010), on such a pasture, which is dominated by the species of Festuca rubra, the pastoral value is highly heterogeneous, from mediocre to good, with a yield of 5-15 t/ha green mass, respectively $0.5-1.5$ LU/ha.

Subsequent to the vegetation scoring of the studied pasture area, the pastoral value, grassland category, load and grazing capacity of the pasture were determined, as it is shown in the Table 1.

Following the operations to determine the analyzed pasture production, the global production was calculated as 13.10 (t/ha green mass) and the unconsumed vegetal residues, so-called refuses were 1.62 (t/ha green mass). Thus, the consumable pasture production is equal to 11.48 ( $t$ /ha green mass). Aspects during the operations of determining the pasture productivity are shown in the Figures 1, 2.

The grass using rate was calculated based on the obtained results: $\mathrm{K}=87.6 \%$ 
Tab. 1. Pastoral value and grazing capacity of the pasture

\begin{tabular}{cccccc}
\hline \multicolumn{2}{c}{ Bonitation coefficients } & Class & & Pasture category & LU/ha \\
\cline { 1 - 2 } Pastoral value & Bonitation grade & & & Medium & 0.81 to 1.00 \\
\hline 1.9 & 41-50 points & VI & M
\end{tabular}
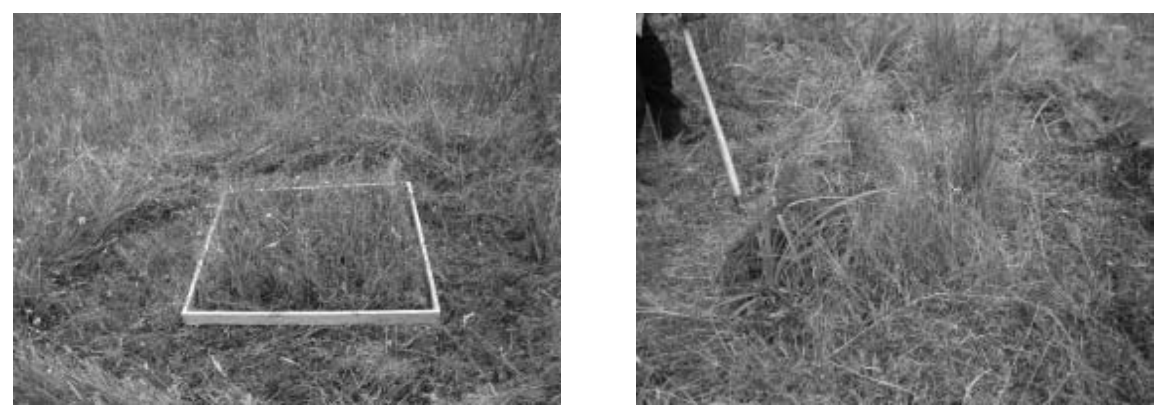

Fig. 1. Aspects during mowing grass samples to determine production of the pasture
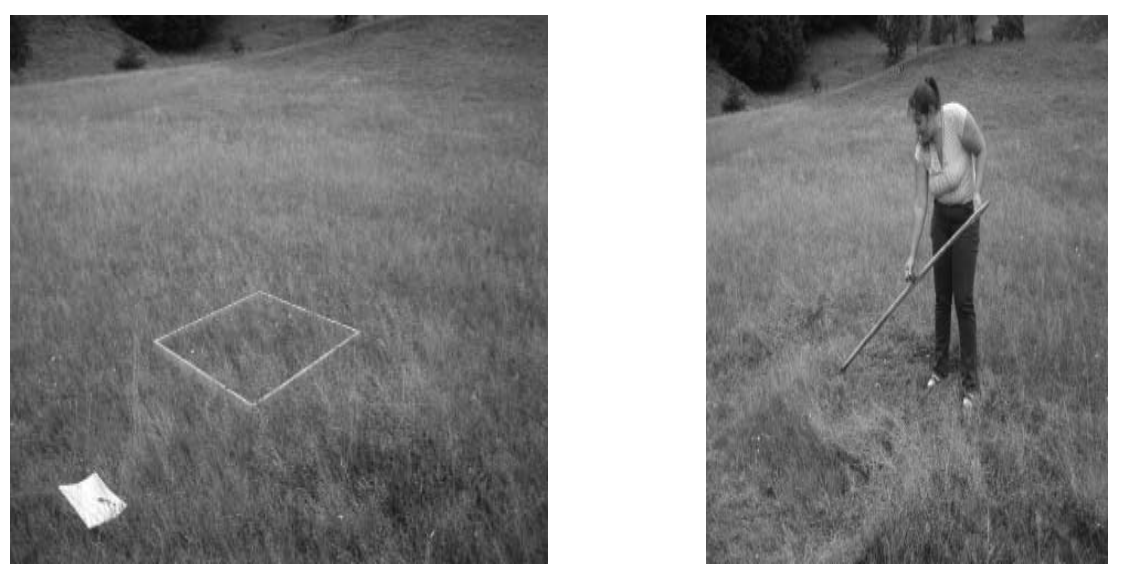

Fig. 2. Aspects on mowing refuse from the pasture

The results obtained with the use of mixed grassland show a mean value pasture with a yield of 13.10 (t/ha green mass), this value falling in the data presented in the literature. Pasture can support a load of 0.81 to $1.00 \mathrm{LU} / \mathrm{ha}$, equivalent to 5.7 to 7.1 sheep/ha.

Compared to previous research conducted on such a grassland dominated by Festuca rubra and Agrostis capillaris, Vintu at al. (2007), found that pastoral value is ranging between 2.0 and 2.5 , its grazing capacity between 1.0 and $1.2 \mathrm{LU} / \mathrm{ha}$. These values are higher than those determined in the research carried out on the pasture where the Surdesti villagers' sheep and goats are grazed year after year. One of the causes of low yields obtained on the pasture is due to soil nutrient depletion because of lack of fertilizer application. Sheep grazing leads to over nitrogen-fertilization on certain portions, which reduces the ratio of useful plants and multiplying of weeds. Another negative consequence might be very early spring grazing that is performed today in the hillside regions, because it is harmful to soil and pasture vegetation. The grazing performed with a large number of livestock declines the resistance to treading, the phenomenon of soil compaction appears, the grassy carpet thins towards destruction, and then slopes erosion occurs. Mowing pastures too lately, after weed seeds reached maturity, favors their 
expansion, which leads to decrease the feed value of the pastures.

\section{CONCLUSION}

Livestock grazing on national realm is an ancient practice. Grasslands where livestock are habituated are considered renewable natural resources, but to maintain this, a balance between the elements that are necessary for the grazing management is required.

Annual grazing of sheep and goats in the hills of Maramures County has negative consequences on the grassy carpet, leading to a decrease in the pasture yield and implicitly grazing capacity. Actions are required to improve grasslands such as: combating of soil compaction and erosion, correction of soil extreme reaction, combating woody and harmful herbaceous vegetation, destroying molehills, land leveling, etc.

Learning these factors favors keeping valuable grasslands because only through a rational grazing one can keep the resources offered by the permanent grassland vegetation.

\section{REFERENCES}

1. Bagella S, Salis L, Marrosu GM, Rossetti I, Fanni S, Caria MC, Roggero PP (2013). Effects of long-term management practices on grassland plant assemblages in Mediterranean cork oak silvo-pastoral systems. Plant Ecology 214(4):621-631.

2. Caballero $\mathrm{R}$ (2007). High nature value (HNV) grazing systems in Europe: a link between biodiversity and farm economics. Open Agric J 1:1-19.

3. Marușca T, Blaj VA, Rusu M (2012). Tehnologii de crestere a calorii pastorale pentru pajistile montane. ASAS București.

4. Marușca T, Mocanu V, Cardașol I, Hermenean V, Blaj AV, Oprea G, Tod MA (2010). Ghid de reproducere ecologica a furajelor de pajisti montane. Ed. Universitatii Transilvania din Brasov, $22 \mathrm{p}$.

5. Metera E, Sakowski T, Słoniewski K, Romanowicz B (2010). Grazing as a tool to maintain biodiversity of grassland - a review. Animal Science Papers and Reports 28(4):315-334.

6. Rook AJ, Dumont B, Isselstein J, Osoro K, Wallis DE Vries MF, Parente G, Mills J (2004). Matching type of livestock to desired biodiversity outcomes in pastures: a review. Biological Conservation 119, 137-150.

7. Rotar I, Vidican R, Sima N (2009). Cultura pajiştilor şi a plantelor furajere. Lucrări practice. Ed. Risoprint. Cluj Napoca. 142-143 p.

8. Vintu V, Samuil C, Iacob T, Postolache S, Popovici IC (2007). The biodiversity and agronomic value of mountain permanent grasslands from the North-Eastern part of Romania. In: Permanent and temporary grassland: plant, environment and economy. Proceedings of the 14th Symposium of the European Grassland Federation, Ghent, Belgium, 528-531 p. 